\title{
Innovations and Investments as a Sources of Economic Growth in Azerbaijan in Pandemic Conditions
}

\author{
Gulshen Zahid qizi Yuzbashiyeva ${ }^{1}$, Samira Huseyn qizi Abasova ${ }^{1 *}$ \\ ${ }^{1}$ Economy Institute of Azerbaijan National Academy of Sciences, Baku, Azerbaijan \\ *Email: abasovasamira@rambler.ru
}

\begin{abstract}
This article examines the issues of ensuring economic growth in the economy of Azerbaijan. Authors consider the innovative stages of development for Azerbaijan national economic growth based on modern technologies and attracting investment. Investments for implementing modern innovations in Azerbaijan have played a leading role in increasing the export potential of hi-tech products and their competitiveness in the world market. This article has considered some indexes (index of economic freedom, index of "economic complexity") and the position of Azerbaijan in the ranking of the CIS countries for 2013-2020. The gradual and consistent economic growth of Azerbaijan contributes to the stability and efficiency of the economy and develops the scientific, technical and technological potential of the industry and the qualifications of personnel. Increasing the level of investments in the national economy of Azerbaijan will allow moving from a stage driven by factors to a stage driven by investments that ensure sustainable development of the economy through scientific, technical and technological developments.
\end{abstract}

Keywords: Innovations, Investments, Index of economic freedom, "Economic complexity" index, Pandemic and economic growth, Economic growth model, Azerbaijan economic growth.

\section{INTRODUCTION}

In just over two years, the pandemic has shackled economic growth in many countries. In a pandemic, many states spend money on health care and sanitation, preventive sanitary measures, the safety of passenger traffic, and customs procedures. With the announcement of the pandemic, many services switched to the online format, and many retail outlets, shops, pharmacies, restaurants and cafes switched to serving customers at home through the delivery of goods for online orders.

There is also learning through online training programs and the provision of online money transfer services in the financial sector. Despite the transition of many services to the online format, industrial production continues to create industrial products in the same way, taking into account WHO's requirements.

As well known, economic growth is possible subject to the application of innovative transformations, which use various investments at the expense of domestic funds and attract foreign funding. Consequently, the sources of economic growth are mainly innovation and investment.

\section{RESEARCH METHODOLOGY}

While writing this article, the authors have considered some statistical indicators of different countries' investments to solve pandemic problems. Authors have analysed Azerbaijan's technology and innovation potential in pandemic terms, some indexes of Azerbaijan economic growth with other countries of former Soviet Union republics using comparison method of investigation. The used data are based on the official data of www.ivf.org and https://www.wipo.int WIPO (World Intellectual Property Organisation) in 2013-2020 years. More indicators expressed in $\%$ and places of countries among other counties of the world, in a monetary unit of different countries and USA dollars. The authors used some indexes because more statistical indicators have not been published by Statistic Committees of former Soviet Union Republics. The authors have used the observation and research methods in Chapter 3, statistical and 
research methods in Chapter 4, statistical and expert assessment method of investigating in Chapter 5 of this article.

\section{INNOVATION AND INVESTMENT AS SOURCES OF ECONOMIC GROWTH}

As Wheelan correctly notes, our standard of living predetermines productivity growth. If productivity increases by $2 \%$ per year, we become richer by $2 \%$ every year, since we can use the same factors introduced into production and produce goods $2 \%$ more, or get the same volume of production, use $2 \%$ fewer factors introduced into production. Productivity gains make you richer no matter what happens in the rest of the world. It depends on investments in physical capital, human capital, R\&D and increasing the efficiency of state institutions, innovation and technical and technological progress [1].

Innovation, being the main factor in high-quality economic growth, influences the dynamics of GDP. Their impact on the rate of economic growth is manifested due to an increase in labour productivity and an increase in production efficiency. In addition to a quantitative increase in production, high-quality economic growth is accompanied by many structural, technological and other changes. Innovation drives quality economic growth.

As a result of innovation, there is a redistribution of resources in the economy to use them more efficiently, leading to a change in its structure. The sources of economic growth are:

- Innovative support of economic growth. Opportunities for an economic breakthrough through innovative support and flexible economic development are relevant in current conditions. To solve this problem, it is necessary to more actively introduce into practice the developed methodological foundations of flexible development and the constructed conceptual model of the theoretical construction of the mechanism for its provision, including the patterns of formation of the potential for the development of flexibility, its basic value and the scope of manifestation. New methodological approaches will provide the undoubted effect to the analysis of this problem, and the proposed new directions of theoretical research of flexible development will develop the ability of enterprises to flexible development, increase their business activity and the economic growth of the country and regions. The active introduction of innovations in all spheres of the economy, from research and development to marketing (technical and educational, managerial and many others), will ensure growth based on the innovations already introduced [2].

Innovation itself is not a highly profitable activity, but the modernisation of production and management through innovation will ensure high economic growth;
- Investment support for economic growth. The development and achievement of innovations, ensuring a sustainable level of development, maintaining a decent standard of living, and the country's socio-economic situation is impossible without investment. Material factors of production are buildings, machinery, equipment, vehicles from stocks of physical capital. The capital accumulated at a certain point in time forms production assets. They provide a certain level of production of goods. The desire to increase the production of goods can be realised by the accumulation of capital, i.e. an increase in the quantity and quality of the funds produced [3-4].

Changes in the volume of functioning capital over time to flow. However, investment is the main factor in economic growth and implements economic and social progress. The trend is to move away from closeness in all its manifestations - in the transition to "open innovation" and global innovation networks, in the reassessment of the significance of various kinds of "zones" (closed innovations in military fields).

Secondly, it is a certain idealisation of foreign experience and the combined use of various Western approaches. Not one model was chosen, but several at once. We can see more subjects - the technoparks, the technopolises considered and partially adapted in the "City" (UAE). Combining elements of different models is a challenging task since it is not easy to achieve synergy with this approach [5].

Structural restructuring presupposes, first of all, the leveling of conditions for competition and competitiveness by reducing costs and increasing labour productivity. There is a certain growth potential in the economy of Azerbaijan, not related to export. Under the current conditions, we can see the systemic changes that stimulate exports of hi-tech products, competitiveness, and import substitution. One of the modern sources for ensuring economic growth could be:

- reducing the level of the shadow economy, creating conditions for the development of the entrepreneurial activity, increasing its activity and competition;

- recreation of requirements for the development of production of "simple things" - a) improving quality characteristics; b) reducing dependence on the import of simple things;

- technological renewal, increasing labour productivity of existing industries - diversification;

- industrialisation - the creation of new industries, in traditional ones - an increase in the degree of processing of resources (development of new technological redistributions with an export orientation);

- development of infrastructure, agriculture, housing and communal services. 
The approval of the Strategic Road Maps for the main sectors of the economy and national economy stimulates the development of entrepreneurial activity in the Republic of Azerbaijan by expanding state marketing activity following the progressive world practice. To ensure the effective integration of the national economy into the world economy, The Center for Reform Analysis and Communication [6] should expand the enlightenment activities performed to solve the marketing mentioned above problems.

\section{ANALYSIS OF THE ECONOMIC SITUATION OF AZERBAIJAN IN THE CONDITIONS OF THE PANDEMIC}

Shimon Peres noted: "...the Americans are inventing something new because they believe in tomorrow, and the Israelis are inventing because they don't like today" [7-8]. The combination of these two directions will contribute to creating the foundations for sustainable growth and development, for the harmonious development of the economy, i.e. representation on the market of many industries with high productivity and competent coordination of reserves and resources. The importance comes from the fact that the economy must meet modern development requirements, the requirements of high technologies and services, coupled with the necessary reforms.

During the pandemic, many countries faced economic and social difficulties. It should be noted that many European countries, the USA, Israel, China, and Russia developed strategic plans to combat the pandemic, invested in the industry in scientific laboratories for the early creation of vaccines, and solved numerous problems of various sectors of the economy. It is these countries that have a sustainable capacity for economic recovery. Switzerland and Germany took the top two spots thanks to their economies' agility, evidence-based and evidence-based approach to mitigate restrictive measures without sacrificing public health and safety [9].

At the same time, strengthening the world economy is going on in parallel with the solution of the problems of vaccination. It should be noted that the recovery process is proceeding differently in different countries due to the high uncertainty. In this situation, the main task of the state is to ensure the sustainability of the industrialisation process by pursuing an appropriate actual and consistent policy.

Increasing economic complexity is impossible without defining real priorities for growth and development. It is advisable to build state policy based on the definition of priority areas, focusing resources on them. It is also essential to pay attention to the innovative stages of growth and development of the economy by attracting investments based on modern, attractive approaches. New technologies are based on competitiveness improvement, on up-to-date scientific, technical and technological developments. Technological achievement could not form without personnel qualifications. An increase in the level of investment in the economy will allow the transition from a factor-driven stage to an investment-driven stage.

In conditions when there are specific difficulties such as fluctuations in oil prices on the one hand and the coronavirus pandemic, on the other hand, Azerbaijan is a donor country and donated $\$ 10$ million to WHO. Table 1 gives comparative data on the volume of investments and GDP (in\%) share in developed countries and the CIS countries.

At the beginning of the pandemic, some developed countries were able to respond quickly and have a high degree of preparedness to respond to the challenges of the crisis. Despite:

a) the high expenditures associated with the war,

b) the restoration of territories and,

c) the fight against coronavirus,

the direct and guaranteed external public debt of Azerbaijan at the end of 2020 has amounted to $\$ 8,821.5$ million. About $20.7 \%$ of GDP (3\% less than in 2019) equals $\$ 5,289.6$ million, direct government borrowings. For comparison, note that $\$ 2,810.8$ million are the government securities in foreign currency, $\$ 721.1$ million - contingent liabilities (economy and militaryindustrial complex of Azerbaijan). In 2020 about $\$ 1,085.1$ million was allocated to service the external public debt, and about $\$ 816.4$ million of these were spent on repaying the principal debt, approximately $\$ 268.7$ million - on interest payments [9].

At the conference "A New Look at the South Caucasus: Post-Conflict Development and Cooperation", President Mr I. Aliyev noted that to achieve the best results in the world, it is necessary to reduce Azerbaijan's external debt to $10 \%$. Azerbaijan is independent of external aid. The total amount of direct investments attracted from abroad to Azerbaijan in 2020 amounted to $\$ 4.5$ billion, to the non-oil sector - approx. $\$ 605.6$ million [8]. In 2020 GDP decline was equal to $4.3 \%$ due to restrictions on COVID-19 and in case of reduction in oil production as part of the OPEC + framework [9].

The pandemic has increased the value of innovative projects. In the context of the pandemic, many government organisations, business and financial subjects, etc., switched to online regulating, online administrating, online education and training, online trading, began to use the capabilities of e-government, ebanking, e-order, etc. 
Table 1. Investments by various countries of the world in the fight against the pandemic www.ivf.org [9-10]

\begin{tabular}{|l|c|c|}
\hline \multicolumn{1}{|c|}{ Countries } & Investment in the fight against the pandemic & Share in GDP (\% of GDP) \\
\hline USA & 2.3 trillion US dollars & 11.0 \\
\hline $\begin{array}{l}\text { European } \\
\text { countries }\end{array}$ & 37 billion Euro & 0.3 \\
\hline Italy & 25 billion Euro & 1.4 \\
\hline Spain & 8.9 billion Euro & 0.7 \\
\hline Turkey & 100 billion tl & 1.5 \\
\hline \multicolumn{2}{|c|}{ Former Soviet Union republics } \\
\hline Azerbaijan & 2.5 billion manat & 3.1 \\
\hline Belarus & 1 million dollars of USA & 0.7 \\
\hline Georgia & 1 billion lari & 2.0 \\
\hline Kyrgyzstan & 9.4 million dollars of USA & 1.0 \\
\hline Russian & 0.3 trillion rubl & 0.3 \\
\hline Federation & 10 trillion soms & 1.5 \\
\hline Uzbekistan & & \\
\hline
\end{tabular}

The negative consequences of the pandemic in Azerbaijan can be called:

- a decline in economic activity within the country, between Azerbaijan and other countries;

- fluctuations in oil prices in the world which affects the national economy of the republic;

- low economic growth rates in 2019-2020, which also reflects the consequences of the pandemic.

Weak dynamics of economic growth was caused by the easing of monetary policy, accelerated spending of state budget funds and some conjunctural factors [11]. Due to the pandemic in 2019-2020, there has been a significant weakening in world economic growth due to a slowdown in industrial activity and world trade. The slowdown in the growth of external demand and the OPEC + agreement negatively impacted the dynamics of Azerbaijan's exports. There is also a decline in oil prices against the backdrop of a slowdown in global economic growth.

But the subsequent growth in oil and gas in 2021 contributed to some straightening of the situation in the economy. Authors suggest considering some domestic factors [12] - strong monetary policy and expenditures for a national innovation project. Implementation of strong monetary policy and increased spending on national projects [13] will help revive the economy. The forecast is mainly associated with negative risks. The main risks related to the economic growth forecast include a weakening global economy, increased trade tensions, and domestic factors.

\section{MODEL OF SOCIO-ECONOMIC DEVELOPMENT OF AZERBAIJAN UNDER PANDEMIC CONDITIONS}

Conducting economic reforms in Azerbaijan and pursuing a policy of "openness" for 30 years made it possible for the economy to achieve certain successes. Azerbaijan has its model of socio-economic development and public administration (a set of features that determine the place and role of the state in political systems) [4]. The characteristic features of this development model are:

- strong and effective state power;

- development of all forms of ownership (striving to achieve an optimal balance between the public and private sectors, taking into account national interests);

- increasing the importance of privatisation as a means of attracting interested investors;

- multidirectional foreign economic policy;

- the basis of the economic model is social policy.

The current economic model includes five main directions of development that are interdependent from each other. These directions take into account the peculiarities of the economic policy of Public Administration and the national mentality. They are as follows [14]:

- revealing the role of the state in management or "a model of strong and effective government"; 
- the efficiency of the investment process or "model of investment inflow", where investments are part of the process of economic development;

- "model of export development" for solving the problems of import substitution and the concentration of funds for the development of the country's economy;

- "model of priority development of industry and agriculture";

- effective social policy is the basis of the economic model.

The result of the reforms was an improvement in the ranking of countries in terms of economic freedom (see table 2).

As we know, the index of economic freedom (Index of Economic Freedom) - demonstrates the results of the analysis of changes in political and economic factors to determine the priority economic development of the state. The experts of this organisation define economic freedom as the result of state non-intervention. As shown in Table 2, Azerbaijan improved its position (from 91 in 2016 to 44 in 2020), and in our country, this process was going on consistently.

This is the result of the ongoing economic reforms in Azerbaijan and the policy of "openness", which made it possible for the economy to achieve certain successes. Azerbaijan has its model of socio-economic development and public administration, which also gives good results on the lands returned from the occupation within 44 days.

According to the head of the Central Bank of Azerbaijan, Mr E. Rustamov, "...are expected the good results on the current account of the balance of payments by the end of 2021" [13]. At the end of the year's first half, the current account surplus amounted to $8 \%$ of GDP. The oil factor mainly influences the balance of payments indicators, but oil prices are growing in surplus in the oil and gas sector in the first half of 2021. amounted to $\$ 4.6$ billion (an increase of $40.7 \%$ ). In the non-oil sector, the deficit amounted to $\$ 2.7$ billion (an increase of $1.8 \%$ ) [4]. This all contributed to some improvement with the index of "economic complexity". (Refer Table 3.)

As shown in Table 3, positions on the "economic complexity" index have improved in Azerbaijan. True, this is not yet a very good position, but the ongoing fundamental changes will give good results which selected priority areas of sustainable and dynamic development of the country. At the moment, there is a process of combining development models in the republic:

- At first, the correlation between the models of economic development "strong and effective

Table 2. Rating of the CIS countries by the level of economic freedom * Index of Economic Freedom [15]

\begin{tabular}{|c|c|c|c|c|c|c|c|c|c|c|}
\hline \multirow[t]{2}{*}{ Countries } & \multicolumn{2}{|c|}{2016} & \multicolumn{2}{|c|}{2018} & \multicolumn{2}{|c|}{2019} & \multicolumn{2}{|c|}{2020} & \multicolumn{2}{|c|}{$\begin{array}{l}\text { Increasing }(+) \\
\text { or decreasing } \\
(-) \text { for } 4 \text { year }\end{array}$} \\
\hline & index & place & index & place & index & place & index & place & index & place \\
\hline Azerbaijan & 60.2 & 91 & 64.3 & 67 & 65.4 & 60 & 69.3 & 44 & -9.1 & +47 \\
\hline Belarus & 48.8 & 157 & 58.1 & 108 & 57.9 & 104 & 61.7 & 88 & -39.2 & +69 \\
\hline Georgia & 72.6 & 23 & 76.2 & 16 & 75.9 & 16 & 77.1 & 11 & -4.5 & +12 \\
\hline Kazakhstan & 63.6 & 68 & 69.1 & 41 & 65.4 & 59 & 69.6 & 40 & -6.0 & +28 \\
\hline Kyrgyzstan & 59.6 & 96 & 62.8 & 78 & 62.3 & 79 & 62.9 & 81 & -3.3 & +15 \\
\hline Latvia & 70.4 & 36 & 73.6 & 28 & 70.4 & 35 & 71.9 & 32 & -1.5 & +4 \\
\hline Lithuania & 75.2 & 13 & 75.3 & 19 & 74.2 & 21 & 76.7 & 16 & -1.5 & -3 \\
\hline Moldova & 57.4 & 117 & 58.4 & 105 & 59.1 & 97 & 62.0 & 87 & -4.6 & +30 \\
\hline $\begin{array}{l}\text { Russian } \\
\text { Federation }\end{array}$ & 50.6 & 153 & 58.2 & 107 & 58.9 & 98 & 61.0 & 94 & -10.4 & +59 \\
\hline Tajikistan & 51.3 & 149 & 58.3 & 106 & 55.6 & 122 & 52.2 & 155 & -0.9 & -6 \\
\hline Turkmenistan & 41.9 & 174 & 47.1 & 169 & 48.4 & 104 & 46.5 & 170 & -4.6 & +4 \\
\hline Ukrain e & 46.8 & 162 & 51.9 & 150 & 52.3 & 147 & 54.9 & 134 & -8.1 & +28 \\
\hline Uzbekistan & 40.6 & 166 & 51.5 & 152 & 53.3 & 140 & 57.2 & 116 & -16.6 & +50 \\
\hline Estonia & 77.2 & 7 & 78.8 & 7 & 76.6 & 15 & 77.7 & 10 & -0.5 & -3 \\
\hline
\end{tabular}


Table 3. Index of "Economic complexity" of the former USSR countries for 2013-2019 https://atlas.cid.harvard.edu/rankings [16]

\begin{tabular}{|c|c|c|c|c|c|c|c|c|}
\hline \multirow{2}{*}{ Countries } & \multicolumn{3}{|c|}{$\begin{array}{c}\text { Economic complexity } \\
\text { rating }\end{array}$} & \multicolumn{3}{|c|}{ O ccupied place } & \multirow{2}{*}{$\begin{array}{l}\text { Rating changes } \\
\text { for } 6 \text { years } \\
\text { (+ growth; } \\
\text { - decrease) } \\
\text { (2013-2019) }\end{array}$} & \multirow{2}{*}{$\begin{array}{l}\text { Changes in the } \\
\text { occupied place } \\
\text { over } 6 \text { years } \\
\text { (+ improvement } \\
\text { - deterioration) } \\
\text { (2013-2019) }\end{array}$} \\
\hline & 2013 & 2015 & 2019 & 2013 & 2015 & 2019 & & \\
\hline Azerbaijan & -1.31 & -1.07 & -1.19 & 125 & 114 & 120 & +0.12 & +5 \\
\hline Belarus & 1.18 & 0.82 & 0.83 & 22 & 33 & 31 & +0.35 & -9 \\
\hline Georgia & -0.08 & -0.18 & -0.01 & 64 & 70 & 63 & $+0,01$ & -1 \\
\hline Kazakhstan & -0.91 & -0.52 & -0.32 & 109 & 85 & 78 & +0.59 & +31 \\
\hline Kyrgyzstan & 0.25 & 0.13 & -0.04 & 48 & 55 & 65 & -0.29 & -17 \\
\hline Latvia & 0.66 & 0.55 & 0.67 & 37 & 41 & 37 & -0.10 & 0 neutral \\
\hline Lithuania & 0.68 & 0.62 & 0.79 & 36 & 36 & 33 & -0.11 & +3 \\
\hline Moldova & 0.14 & -0.15 & -0.16 & 53 & 67 & 68 & -0.30 & -15 \\
\hline $\begin{array}{l}\text { Russian } \\
\text { Federation }\end{array}$ & -0.08 & 0.17 & 0.12 & 65 & 51 & 52 & +0.20 & +13 \\
\hline Tajikistan & -1.12 & -1.14 & -0.74 & 112 & 117 & 97 & +0.30 & +15 \\
\hline Turkmenistan & -1.17 & -1.10 & -0.70 & 117 & 115 & 95 & +0.47 & +22 \\
\hline Ukraine & 0.52 & 0.30 & 0.30 & 43 & 46 & 47 & -0.22 & -4 \\
\hline Uzbekistan & -0.71 & -0.69 & -0.48 & 98 & 97 & 87 & +0.23 & +11 \\
\hline Estonia & 0.92 & 0.99 & 0.92 & 30 & 28 & 29 & 0 neutral & -1 \\
\hline
\end{tabular}

government" and the model of "service economy" creates conditions for developing a market economy. The state does not directly interfere in the economy. The state forms the legislative framework and indirectly regulates the market;

- Secondly, it is necessary to combine the development of the economy along the path of the "model of investment inflow" and the development of consumption growth;

- Thirdly, it is necessary to correct the "export development model" and transfer to the criterion of balancing foreign trade and commodity turnover;

- Fourth, the "model of priority development of industry and agriculture" creates the basis for stable economic growth, develops specific industries and enhances the importance of product competitiveness;

- Fifthly, an effective social policy contributes to an increase in the population's well-being.
In this situation, the measures to prevent the spread of coronavirus play a negative role in world markets. This leads to such consequences as:

- the emergence of an inadequate situation in the stock markets due to investors' uncertainty, which leads to a decline in stock prices in the world's largest markets. In this case, the influence on the markets is carried out in three directions:

a) decline in business activity in common;

b) reduced business activity in local markets;

c) uncertainty in financial markets;

- decrease in production activity, which will negatively impact the country's economy. The low profitability will lead to significant economic losses. It will affect people who are not employed in permanent and formal fixed-pay jobs, in piecework, in the informal sector. They are most vulnerable to economic shocks. 
Their loss of income leads to a decrease in their activity, consumption and expenses. The downturn in business activity will negatively affect industries and those workers, low-income families who in reality should not be negatively affected;

- to the dependence of macroeconomic indicators on the oil factor. Consequently, the economy in the postcoronavirus period will go through certain difficult stages;

- to a one-sided and primitive industrial structure. In the current conditions, the dynamic development of the economy is formed due to inertial (preservation of the structural parameters of previous development) and transformational (a sharp change in the existing structure of industry output and the nature of the dynamics of the main components of GDP) factors. Both factors are at work today.

It should be noted that the situation in Azerbaijan is beginning to improve, but the manufacturing industries are still lagging behind the fuel and energy complex of Azerbaijan. The current situation demonstrates the polarisation effect in the development of the extractive and manufacturing industries.

It is known that resources create material conditions for economic growth, but resources do not determine success. Great Britain began its development with coal, the USA created the developed economy through oil, but no one said they were raw materials appendages. Oil and oil products have helped achieve the foundations of sustainable development for Azerbaijan and have helped create foundations for the post-oil economy. Oil exports subsidise other sectors of the Azerbaijan national economy. Human capital is related to productivity. Productivity is the efficiency with factors that influence the production and export of hi-tech products [17].

Productivity is influenced the hi-tech technologies, specialisation in producing process and personnel skills. All of the factors are functions of human capital. Human capital combines inherent human skills (education, intelligence, experience, creativity, charisma, entrepreneurial ability, the uniqueness of the combination of skills and knowledge). Human capital is a kind of "economic passport". Human capital in a modern economy is a more important form of capital that contributes to wealth creation and growth [18].

There is a relationship between the level of a country's human capital and its economic well-being, but there is no relationship between natural resources and the standard of living. For example, Japan and Switzerland are the richest countries in the world; although they are not endowed with natural resources, they have high per capita incomes. On the contrary, countries of Africa (Nigeria for example), countries of the Middle East, the United Arab Emirates, CA, Russian Federation,
Azerbaijan, Kazakhstan have significant oil and gas reserves but have a low per capita capital income.

It is advisable to recreate and develop new points of growth by implementing interconnected special national sectoral and regional programmes using a complex of monetary, tax, tariff, cluster instruments, stimulating demand [19].

The Azerbaijanian government is doing a lot of work to improve the current situation. Azerbaijan has prepared a draft "National Export Strategy", which identifies 15 target markets [20] and 120 varieties of exported products. The growth rates and directions of manufacturing industries' development will shape the future of economic development, determine the optimal balance between orientation to domestic markets and orientation to foreign markets.

\section{CONCLUSION}

To get out of this situation, it is necessary to rely on identifying existing and potential national competitive advantages in the main directions on new technological order's formation through corresponding concentration of financial, investment, information and intellectual resources of republic. This requires the solution of the appropriate investment, structural, industrial, scientific, technical and technological and other components of the country's sustainable development policy. Creating an economic model based on innovation with progressive inequality is necessary. These innovations will concentrate on the direction of growth and transition to a new qualitative state. This model suggests focusing on:

- achieving this goal by realising the potentials of innovation, investment and industry infrastructure (3 "I");

- taking advantage of the consistency, constancy and continual gradualness of the reforms ( 3 "C");

- strategic guidelines by strengthening the processes of coordination, complexity and cooperation ( 3 "C");

- reaching an agreement between three forces: state, science, and business subject ( 3 "S").

In this research, authors consider some positive (an increase in production, national wealth, the country's importance in the international division of labour, an increase in the standard of living of the population and an improvement in working conditions) and negative (deterioration of the country's ecological situation, the problem of unemployment, depletion of resources, overpopulation of cities) results of economic growth which advisable to take into account in Azerbaijan socioeconomic development programme preparing.

This revealed the need to create conditions not for economic growth of an ineffective structure but for real innovative growth and development, which implies an 
increase in the structural quality of the economic system and the expansion of its capabilities in terms of innovation.

As a result, we could see a new generation of investment policies where the main goal is growth and sustainable economic development. They demonstrate the systematic integration and management of sustainable development through specific indicators and mechanisms at domestic and international levels.

The distinctive characteristics of this generation of investment policies recognise the role of investment as a driving force of economic growth, the desire to achieve social goals simultaneously with economic ones, and the need to improve the effectiveness of policies to attract investment resources. Protection of state interests plays an important role in determining the direction of state investment policy. The transformation of industries, the decrease in imports of components for agricultural machinery, drilling equipment, ferrous metallurgy products, etc., are essential measures of the Azerbaijan government.

The transition to the concept of sustainable growth means identifying priorities for innovative development based on the existing potential, a real assessment of the situation and creating conditions for a new generation of scientists and specialists in the field of high technologies.

\section{REFERENCES}

[1] C. Wheelan, B.G. Malkiel, Naked Economics: Undressing the Dismal Science (Fully Revised and Updated) Paperback, April 19, 2010. Retrieved from: https://www.amazon.com/Naked-EconomicsUndressing-Science-Revised/dp/0393337642

[2] O.Yu. Chelnokova, An innovative growth model of the economy [Modeli innovacionnogo rosta ekonomiki] // Bulletin of Saratov University. New Ser. A series of economics. Management. Law [Izvestiya Saratovskogo universiteta. Nov. Ser. Seriya Ekonomika. Upravlenie. Pravo] 17(4) (2017) 413-417. DOI: https://doi.org/10.18500/1994-25402017-17-4-413-417 Retrieved from: https://cyberleninka.ru/article/n/modeliinnovatsionnogo-rosta-ekonomiki

[3] O.M. Turygin, Investments as a source of economic growth: a comparative analysis of Russia and other countries [Investicii kak istochnik ekonomicheskogo rosta: sravnitel'nyj analiz Rossii i drugih stran] // Modern problems of science and education [Sovremennye problemy nauki i obrazovaniya], No. 6, 2014. Retrieved from: https://science-

education.ru/ru/article/view?id=16427 (accessed date: 03.12.2021).
[4] I.A. Nikolaev, T.E. Marchenko, O.S. Tochilkina, Investments as a source of economic growth [Investicii kak istochnik ekonomicheskogo rosta], M.: Publishing House of the Institute of Strategic Analysis, 2019, 27 p. Retrieved from: file:///C:/Users/User/Desktop/I.A\%20Nikolayev\%2 0-\%20Investments report.pdf

[5] G.Z. Yuzbashiyeva, GDP and Real Economy, Monograph, Baku, Elm, 2019, 112 p. (in Russian).

[6] S.H. Abasova, R.A. Safarov, S.H. Yahya, Macroeconomic Indicators' Implementation for State Marketing Activity: Azerbaijan Case. Proceedings of the VIII International Scientific and Practical Conference 'Current problems of social and labour relations' (ISPC-CPSLR 2020), Advances in Social Science, Education and Humanities Research 527 (2021) 1-8. Retrieved from: $\quad$ https://www.atlantispress.com/proceedings/ispc-cpslr-20/articles

[7] A. Azari, Respect for universal values [Uvazhenie k universal'nym cennostyam]. Economic strategies [Ekonomicheskie strategii] 02 (2009) 16-20. Retrieved from:

http://www.inesnet.ru/article/uvazhenie-kuniversalnym-cennostyam

[8] Sh. Peres, No Room for Small Dreams: Courage, Imagination, and the Making of Modern Israel. Orion Publishing Group, Limited, 2019, 336 p. Retrieved from: https://books.google.az/books?id=PmxYjwEACA

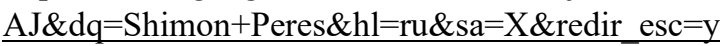

[9] Z. Salimova, Covid-19: quels pays ont le mieux géré l'épidémie? Published on https://nashagazeta.ch, Bern, 9.06.2020. Retrieved from: https://nashagazeta.ch/printpdf/28077

[10] Key Things to Know About COVID-19 Vaccines. Updated Nov. 30, 2021. Retrieved from: https://weillcornell.org/coronavirus-covid19/covid-19-vaccineinformation?utm source $=$ wcmedu\&utm medium $=$ banner\&utm_campaign $=$ covid 19

[11] "A New Look at the South Caucasus: Post-Conflict Development and Cooperation", The conference, Speech by President I. Aliyev, 2020, 13.04.2021. Baku, Azerbaijan. Retrieved from: https://ru.president.az/articles/51088

[12] A.V. Belokopytov, Factors of economic growth in Russia in conditions of sanctions [Faktory ekonomicheskogo rosta Rossii v usloviyah sankcionnnogo pressinga], Russian Journal of Entrepreneurship 17(2) (2016) 145. DOI: https://doi.org/10.18334/rp.16.22.2077 Retrieved 
from:

https://www.researchgate.net/publication/3036003

32 Faktory ekonomiceskogo rosta_Rossii_v uslo viah_sankcionnnogo pressinga

[13] Economy and military-industrial complex of Azerbaijan [Ekonomika i VPK Azerbajdzhana], t.me / ORepsilon. Retrieved from: https://t.me/oreps

[14] E. Naumova, Economic growth models and theoretical foundations of innovative development [Modeli ekonomicheskogo rosta i teoreticheskie osnovaniya innovacionnogo razvitiya], World and National Economy [Mirovoe i nacional'noe hozyajstvo], Published by MGIMO of Foreign Ministry of Russia, No. 4(43), 2017. Retrieved from: $\quad$ https://mirec.mgimo.ru/2017/201704/models-of-economic-growth-and-theoreticalbasis-of-innovation-growth

[15] 2021 Index of Economic Freedom, Azerbaijan. Retrieved from: https://www.heritage.org/index/country/azerbaijan

[16] The ATLAS of economic complexity. Harvard Growth Lab's research and data visualisation tool used to understand the economic dynamics and new growth opportunities for every country worldwide, Azerbaijan. Retrieved from: https://atlas.cid.harvard.edu/rankings

[17] S.H. Abasova, Mechanisms of state regulation of foreign economic innovation processes in countries with developing economies: on the example of foreign economic relations of Azerbaijan with other countries. Novosibirsk, Publishing house CRNS, 2015, 234 p. (monograph in Russian).

[18] G.Z. Yuzbashiyeva, M. Gulaliyev, G. Mamedova, S.T. Abasova, F.R. Salahov, R.R. Askerov, Consumer Surplus Changing in transition from State Natural Monopoly to the Electricity Sector in the Developing Countries: Azerbaijan Case, International Journal of Energy Economics and Policy 10(2) (2020) 265-275 (Received: 28 September 2019 Accepted: 04 January 2020). DOI: https://doi.org/10.32479/ijeep.8909 Retrieved from: http:econjournals.com

[19] R. Arend, Sources of post-crisis economic growth in Russia [Istochniki postkrizisnogo ekonomicheskogo rosta v Rossii] // Economy issues [Voprosy ekonomiki] 1 (2009) 45-52.

[20] V.A. Avatkov, Fundamentals of the foreign policy course of the Republic of Azerbaijan at the current stage. Contours of global transformations: politics, economics, law [Osnovy vneshnepoliticheskogo kursa Azerbajdzhanskoj Respubliki na sovremennom etape, Kontury global'nyh transformacij: politika, ekonomika, pravo] 13(3)

(2020) 118-139. Retrieved from: https://doi.org/10.23932/2542-0240-2020-13-3-7 